IZA DP No. 8015

Do Tertiary Dropout Students Really Not Succeed in European Labour Markets?

Sylke V. Schnepf

March 2014 


\title{
Do Tertiary Dropout Students Really Not Succeed in European Labour Markets?
}

\author{
Sylke V. Schnepf \\ Joint Research Centre, European Commission, \\ University of Southampton and IZA
}

Discussion Paper No. 8015

March 2014

(revised version: October 2014)

IZA

P.O. Box 7240

53072 Bonn

Germany

Phone: +49-228-3894-0

Fax: +49-228-3894-180

E-mail: iza@iza.org

Any opinions expressed here are those of the author(s) and not those of IZA. Research published in this series may include views on policy, but the institute itself takes no institutional policy positions. The IZA research network is committed to the IZA Guiding Principles of Research Integrity.

The Institute for the Study of Labor (IZA) in Bonn is a local and virtual international research center and a place of communication between science, politics and business. IZA is an independent nonprofit organization supported by Deutsche Post Foundation. The center is associated with the University of Bonn and offers a stimulating research environment through its international network, workshops and conferences, data service, project support, research visits and doctoral program. IZA engages in (i) original and internationally competitive research in all fields of labor economics, (ii) development of policy concepts, and (iii) dissemination of research results and concepts to the interested public.

IZA Discussion Papers often represent preliminary work and are circulated to encourage discussion. Citation of such a paper should account for its provisional character. A revised version may be available directly from the author. 


\section{ABSTRACT \\ Do Tertiary Dropout Students Really Not Succeed in European Labour Markets?*}

Tertiary education has been expanding hugely over the last decades, so that tertiary dropout students will constitute a growing distinctive group in future labour markets. University dropout is regularly discussed as a 'negative' indicator. However, research on actual career trajectory of dropout students is virtually non-existent. Using data from the 2011 Programme for the International Assessment of Adult Competencies (PIAAC) this study first compares the percentage of adults with tertiary dropout experience between European countries. Second, we examine whether tertiary dropout is a permanent decision as a considerable part of the literature assumes. In a third step, we investigate characteristics of adults with dropout experience. Finally, we estimate the 'effect' of dropout on employment status and success of entering prestigious professions comparing results of logistic regression analysis and propensity score matching taking individuals' characteristics like socio-economic and demographic background, work experience and cognitive skills into account. Results indicate that conditional on these characteristics and for all countries examined on average those individuals who attended but dropped out of tertiary education fare often better and never worse in terms of career progression than those who never enrolled. These to the knowledge of the author first cross national results on tertiary dropouts' career progression therefore question the purely negative view of tertiary dropout predominant in the literature and at universities.

JEL Classification: $\quad 121$

Keywords: $\quad$ tertiary dropout, labour market chances, European countries, propensity score matching

Corresponding author:

Sylke Viola Schnepf

European Commission, DG Joint Research Centre

Centre for Research on Impact Evaluation (CRIE)

Econometrics and Applied Statistics Unit

Via E. Fermi 2749, TP 361

I-21027 Ispra (VA),

Italy

E-mail: sylke.schnepf@jrc.ec.europa.eu

\footnotetext{
* I thank the DEMM, Universitá degli Studi di Milano, Italy and the German Institute for International Educational Research, Germany for their hospitality during work on this paper and seminar participants of both institutes and Traute Meyer and Jürgen Enders for helpful comments.
} 


\section{Introduction}

Around the world, tertiary education has been expanding hugely over the last decades (Schofer \& Meyer 2005). Across OECD countries, enrolment increased by 25 percentage points between 1995 and 2009 (OECD 2013a). Therefore, tertiary dropout students are constituting a growing distinctive group in the labour market.

Higher entry rates into universities are leading to increasing costs of the tertiary education sector so that policy debate is increasingly evolving around issues of efficiency of the tertiary sector (OECD 2013a, Aubyn et al. 2009). While efficiency is difficult to measure, tertiary student dropout rates can serve as an indicator (OECD 2013a).

Besides the potential importance of dropout rates for efficiency rating of tertiary education, they have been discussed in literature focusing on patterns of educational inequalities. This research examining mainly single countries separately generally indicates that educational inequalities get reinforced during tertiary education, since parental background is often associated with tertiary drop out, in some countries even conditional on upper secondary school achievement (i.e. Powdthavee \& Vignoles 2009 for the UK).

The discussions of dropout as efficiency measure and as a factor contributing to inequality share one assumption: tertiary dropout students do not benefit from tertiary enrolment. In economics, this assumption is associated with the so called credentialism theory. It stipulates that what matters in order to enter prestigious occupations is a graduation certificate. Credentialism is at odds with the human capital (Becker 1962) and signalling theory. Human capital theory is the backbone of the Mincer equation models (Mincer 1974) predicting that each year spent in education accumulates human capital and therefore increases returns to education independent of a successful graduation. Signalling can also be interpreted in the way that enrolment into tertiary education already constitutes a first positive signal for employers and therefore enhances labour market chances even without degree. (Arrow 1973, Matkovic and Kogan 2012).

Despite the importance of the growing phenomenon of tertiary dropout, literature examining this group of labour markets entrants and their career pathway is rare. Davies and Elias (2003) show that while tertiary dropouts have lower chances of employment than graduates, about half of them move into 'graduate-track' type occupations and earn similarly to graduates in the UK. Using data for the US, Flores- 
Lagunes and Light (2007) conclude that years since highest grade completed have a higher effect on wages for non-graduates compared to graduates conditional on graduation. Matkovic and Kogan (2012) also reject the credentialism theory for Serbia by concluding that dropout is a better predictor of job entry than not starting tertiary education and time spend in tertiary education increases dropouts' employment choices.

This paper's main objective is to examine labour market success of adults having experienced tertiary education dropout. In contrast to existing literature generally focusing on country specific cohorts of tertiary education entrants, we examine tertiary dropout experience of adults aged 20 to 65 across EU countries.

Using data from the 2011 Programme for the International Assessment of Adult Competencies (PIAAC) this study first compares the percentage of tertiary dropouts across countries. Given the unusual dropout measure applied, PIAAC results are compared to figures published by the OECD.

Since most of existing studies assume that dropout decisions are permanent (Stratton et al. 2007), in a second step we examine whether this is true. In addition, descriptive analysis on gender, socio-economic background and cognitive skills by dropout status are provided.

Results indicate that across countries it is rather a common pattern that dropouts attain tertiary education later in their life. As a consequence, we split dropouts into two groups: dropouts with and dropouts without graduation. Dropouts with graduation are compared to tertiary educated and dropouts without graduation to individuals who did not enrol into tertiary education but were eligible due to having completed upper secondary education. These groups are compared in terms of their employment chances and professional positions attained within the labour market. Since dropout students are systematically selected on the basis of individual background and cognitive skills known to be also associated with labour market outcomes, we need to control for these variables to obtain a meaningful estimate of dropout 'effects'. We employ logistic regression analysis and propensity score matching and compare results between both methods.

The paper is structured as follows: Section 2 provides a literature review. Section 3 discusses the data and methodology used. In Section 4 we compare dropout rates between countries and measures. The focus of Section 5 is on 
characteristics of dropout students while Section 6 scrutinises on labour market success of adults with tertiary dropout experience and Section 7 concludes.

\section{$2 \quad$ Literature review}

Dropout is generally ${ }^{1}$ discussed as sub-optima outcome at three levels, the society, the tertiary education systems where the dropout took place and the individual level. Within the society attrition is discussed to bear a negative connotation due to a waste of educational resources which coincides with the notion of dropout being a sign of tertiary education inefficiency (Aubyn et al. 2009, OECD 2013a). At university level some countries like the UK implemented a performance based rating of tertiary education, so that high dropout rates are penalised. For the individual, dropout often might be interpreted as individual failure and waste of resources.

Literature stating that withdrawal patterns reinforce educational inequalities equally assumes no gain through enrolment. These studies generally employ longitudinal data of student cohorts over a short time window to examine dropout decision. Thereby, it is generally assumed that dropout decisions are permanent even though this is not tested for (Stratton et al. 2007).

This purely negative view of tertiary dropout is surprising, given that there is only very limited literature available (Stratton at al 2007, Matkovic and Kogan 2012) on the relationship of tertiary dropout and labour market success.

From a theoretical point of view, individuals' reasons for dropout decisions are likely to be related to their future labour market chances especially if labour market institutions, education systems and student characteristics are considered, which are the main factors ${ }^{2}$ regularly associated with dropout.

In a cross-national context differences in labour market flexibility and education systems are likely to impact on dropouts' career pathways. Focusing on labour market regulations, mechanisms for dropouts' entry into employment might be quite different to mechanisms for their career development. Applying the

\footnotetext{
${ }^{1}$ Manski (1989) discusses dropout as a neutral result of a natural experiment.

${ }^{2}$ Educational institutions are a third main reason discussed for dropout decision but not primarily important for the discussion of labour market success. If students' expectations are poorly matched by the institution and social integration within universities is weak students drop out (Tinto 1975). The focus on the importance of institutions for withdrawal has been developed further by examining the impact of peers (Johnes \& Nabb 2004) and available resources within the institute (Bound and Turner 2007).
} 
'credentialist model' only an attained degree matters for a successful entry in the labour market; years of schooling are not important. This theory cannot predict career progression and is best placed in an 'occupational labour market' that is highly regulated by matching jobs with educational credentials. (Brown 2001) In such a labour market setting, dropouts would not be in an advantage to individuals eligible for but never having attended tertiary education. In contrast, the signalling theory can be attributed to internal labour markets in which once inside the firm promotions to higher level jobs can be achieved by on the job training. Assuming university entry as a 'signal' dropouts would again fare better access to work than equally educated counterparts (Matkovic and Kogan 2012) while it is not quite clear whether signalling helps in terms of career progression. The human capital theory stipulates that every year in education contributes to a gain in labour market chances for both, entry and promotion. Given this theory dropouts would fare better than upper secondary educated adults depending on how long they stayed at university. Matkovic and Kogan (2012) attribute this theory to flexible labour markets where job matching is determined purely by market mechanisms.

Besides focusing on the labour market, also the upper secondary education system might be of importance for explaining dropouts' chances compared to those of upper secondary educated. In the past it has been hypothesised, that the more vocational the school education system is, the lower is the value of vocational education and consequently the lower the chance to reach professional positions for upper secondary educated school leavers (Wolbers 2007). We could therefore assume that tertiary dropouts have an advantage to other upper secondary educated in countries where school-based vocational pathways are common.

In the light of the labour market and education system structures and their impact on dropouts' career chances, the common negative interpretation of tertiary dropout is likely to occur only in occupational labour markets where credentials of a graduation certificate alone give access to professional jobs. However, the limited literature available on career pathways of tertiary dropouts generally indicates that tertiary dropouts do gain to some extent from university enrolment (Davies and Elias (2003) for the UK, Flores-Lagunes and Light (2007) for US, Matkovic and Kogan (2012) for Croatia and Serbia).

This study therefore examines whether dropouts indeed do not benefit from tertiary enrolment in terms of their career pathways in European labour markets. We 
thereby try to investigate whether common country patterns exist in terms of dropouts' employment chances and access to professional careers. It is beyond the aim of this study to explain country differences in mechanisms driving the results since this would need to discuss in-depth each country's labour market institution in terms of flexibility and its interplay with the educational system.

While descriptive results will be presented, the study design must control for skills and socio-economic background which are associated with labour market success (Buchner et al. 2012) as well as with dropout decision: ${ }^{3}$ retention literature reveals a negative association of ability (i.e. Araque et al. 2009, Smith \& Naylor 2001, Montmarquette et al. 2001, Stinebricknen \& Stinebrickner 2013, Powdthavee \& Vignoles 2009) ${ }^{4}$ and socio-economic background (Cingano and Cipollone 2007, Jones \& McNabb 2004, Smith \& Naylor 2001, Powdthavee \& Vignoles 2009) with tertiary withdrawal rate.

\section{Data and methodology}

Data

PIAAC $^{5}$ was organised by the OECD in 2011 measuring adults' development and use of cognitive literacy, numeracy and problem solving skills in 26 countries. The survey covers a variety of characteristics related to skills, like for example formal education, work experience, employment and professional status as well as dropout from formal education and other background variables like gender, family structure and socio-economic status. While the survey organisers had cognitive skills as outcome variable in their mind, future researchers will as well be tempted to use skills as an explanatory variable (in line with this paper). A general problem of this approach relates to the direction of the impact of skill formation on the dependent variable. In this paper we use cognitive skills as a proxy for ability relevant to labour market success and condition on skills for examining dropouts' professional

\footnotetext{
${ }^{3}$ Bennett (2003) discusses self-reported financial hardship in the UK as driving factor for university attrition. In addition, dropout differs by subject area studied (Heublein et al. 2012, Stinebricken \& Stinebricken 2013).

${ }^{4}$ However, Johnes and McNabb (2004) discuss that peer effects are important in the UK by presenting results indicating that academically able males enrolled in a program with low ability peers are more likely to dropout. ${ }^{5}$ PIAAC is the successor of the International Adult Literacy Survey (IALS) and the Adult Literacy and Lifeskills Survey (ALL); however in contrast to previous studies its country cover is considerably higher, data are collected during the same time interval to ensure comparability, and more background information are available as well as different skill measures were used.
} 
progression. Nevertheless, it is equally likely that professional success increases skill levels.

The OECD uses different strategies for the questionnaire design aiming at making survey instruments comparable (see OECD 2013b). ${ }^{6}$ Country survey organisers decided about the sample design which included single stage (for those countries having national population registries as sampling frames) to multistage designs. Cognitive kill questions were administered via computer under supervision of the interviewer and background information was collected via computer-assisted personal interviewing (CAPI). Response rates to the survey were below 50 per cent in Sweden (45 per cent) and Spain (48 percent) and below 60 per cent in the Netherlands (51 per cent), Italy (56 per cent), Poland (56 per cent) and England (59 per cent). Ireland had a comparatively high response rate with 72 per cent. Survey weights are provided and aim at adjusting for non-response and coverage bias. Results for Belgium refer to the Flemish speaking part and results for the UK to England and Northern Ireland only.

\section{Definition of tertiary dropout}

Retention and dropout studies examining characteristics of students withdrawing form tertiary education are employing cross-sectional or panel data and focus on two time points: entry to tertiary studies and 'i' years after entry. This coincides with the definition used by OECD (2013a).

Completion rate $\mathrm{C}$ is defined as number of students having graduated successfully at time point $x+i$ expressed as percentage of students who enrolled in year $x$. As a consequence, completion rates are highly sensitive to the choice of ' $i$ '. The OECD defines ' $i$ ' as the number of full-time study years required completing a degree in the country being under investigation. The dropout rate is the difference between 1 and the completion rate.

Individuals not completing within the years required and students having left tertiary education are equally counted as dropouts (DO). This measure is problematic since students interrupting their studies, students never having intended to complete a degree and part-time students are generally count as dropouts. For different countries, study interruption, so-called 'no-shows' and part-time study as

\footnotetext{
${ }^{6}$ For more details on the survey implementation and any other technical information see OECD 2013b.
} 
well as prolonged study beyond the years required for completing a degree varies. This questions cross-national comparability of the data using a small country specific 'i'. For the calculation of OECD dropout rates cross-sectional instead of longitudinal data are employed for some countries. This method assumes constant student flows for year $\mathrm{x}$ and year $\mathrm{x}+\mathrm{i}$, which might be problematic especially in times of education reform and economic recession. ${ }^{7}$

In contrast, this paper focuses on the experience of tertiary education dropout among adults aged 25 to 64 . Tertiary dropout rates can be derived from two questions asked at the beginning of the PIAAC questionnaire to those respondents who report not being studying for any kind of formal qualification during the time of the interview:

'Did you ever start studying for any formal qualification, but leave before completing it?'

Interviewer instructions state: 'This question refers to programmes as a whole (for example a bachelors programme at university). 2. If the respondent had a temporary break, but continued the programme later, this should not be counted as 'leaving before completing'. ${ }^{8}$

Individuals answering yes were then asked:

'What was the level of the qualification you started studying for? If there was more than one, please report the one with the highest level.' (OECD 2013c) In order to be able to compare national programs in terms of qualification level, national educational attainment information is coded into categories of the International Standard Classification of Education 1997 (ISCED-97, for how national educational programmes are classified, see OECD 1999). ISCED levels 5a, 5b and 6 cover tertiary education. ISCED $5 \mathrm{a}$ and 6 refer to Bachelor, Master and PhD programmes and therefore to the more classical university education. ISCED $5 b$ programmes are shorter, provide less theoretical foundations and prepare for skills needed for entry into specific professions in the labour market.

While this self-reported dropout statement might be subject to measurement error (for example, it is left to the respondent to decide whether change of the subject of the program should count as withdrawal or not), in contrast to the OECD measure

\footnotetext{
${ }^{7}$ I.e. using OECD (2013), dropout rates for countries Belgium, Denmark, Finland, France, Netherlands, Norway and Sweden are based on longitudinal data, but for countries Czech Republic, Poland, Slovak Republic and United Kingdom only on cross-sectional data.

${ }^{8}$ This question is asked after the question on highest qualification obtained.
} 
part-time students, students interrupting their studies, students studying longer and students not having enrolled to complete a degree will not be counted wrongly as dropouts.

For the purpose of the following study an adult with tertiary dropout experience is defined to be anyone with at least upper secondary education who is not in formal education during the interview and reports having dropped out of tertiary education (ISCED 5a, 5b or 6). Individuals who report having dropped out of tertiary education after having already completed tertiary studies are not counted as dropouts since the focus of this paper is on initial dropout. ${ }^{9}$ Adults with tertiary dropout experience can hold upper secondary education but also tertiary education in case they re-enrolled into tertiary education after tertiary dropout and completed their studies.

We restrict our sample to adults aged 25 to 64 who are currently not in education and have attained at least upper secondary education. Individuals who have completed their highest education in another country are not included in the analysis. Taking these exclusions into account sample sizes range from 2,200 in Spain to 5,600 in UK. Given that on average only 14 per cent of upper secondary educated and 8 per cent of tertiary educated report tertiary dropout (see Table 1), sample sizes are too small to be able to estimate subgroups within the drop-out sample.

Item non-response for the variables used in our models is generally negligible. Complex sample design is taken into account for the calculation of standard errors for regression results. Bootstrapping with 500 replications is used to estimate standard errors for results of propensity score matching.

\section{Methodology}

We measure the 'effect' of tertiary dropout on labour market chances, defining labour market success with two binary variables: first, a variable called 'employed' that is equal to 1 if the person is employed and 0 if the person is unemployed or economically inactive. Second we employ a variable called 'manager' which applies only to the subset of individuals currently employed. Individuals working as

\footnotetext{
${ }^{9}$ Surprisingly, on average across countries as many as one third of adults who hold tertiary education and who report tertiary dropout terminated their tertiary studies after already having achieved previously a tertiary degree. The predominant part of those terminated a tertiary study at the same or a lower level than the tertiary degree they had previously obtained. This shows that the group of tertiary educated with drop out experience is very heterogeneous, which further justifies the focus on only those tertiary educated who received their tertiary degree after their dropout experience.
} 
managers or professionals (International Standard Classification of Occuptions 2008: first two categories) are coded as 1 and other individuals 0 . We assume that upper secondary education is the entry qualification for tertiary education.

We use two methodologies for estimating the counterfactual effect: regression analysis and propensity score matching (PSM). Both methods rely on the assumption, that all relevant differences between adults with and without tertiary dropout experience can be captured with observable variables covered in the data set. The PIAAC data set contains a rich set of covariates, given that it includes information on cognitive skills, socio-economic, demographic background and education, which, as discussed above, are important determinants of dropout but also of labour market success. Nevertheless, even with a rich set of controls we cannot discard the possibility of an impact of unobservables, which would lead to a bias of our estimated effect.

Assumptions of the regression analysis for retrieving the counterfactual estimate are more restrictive than those for PSM, given that a linear effect on potential outcomes and common support, an availability of possible combinations of covariates similar to both dropout and other adults, is supposed. We present logistic regression results for coefficients of two explanatory binary variables, dropout with tertiary education and dropout with upper secondary education, for both outcome variables conditioning on a rich set of covariates covering socio-economic background, cognitive skills and work experience.

In contrast, PSM matches those adults with dropout experience to similar adults without dropout experience based on a propensity score. In detail, we apply matching for tertiary and upper secondary educated separately. For both groups, we calculate propensity scores of being a tertiary dropout using probit regression and conditioning on the same rich set of covariates used in the regression design. We then match adults with dropout experience with other adults on basis of their propensity score using nearest neighbour matching with replacement and a caliper and kernel matching thereby excluding off-support individuals. The estimated 'effect' of dropout is then the difference in the outcome measure between both groups. As a consequence, PSM is non-parametric and therefore relaxes the linearity assumption as well as common support is taken into account. Given that it compares dropouts with matched other adults, it measures the so-called 'average treatment effect of the treated' (ATT): i.e. how does dropout experience change labour market chances of 
dropouts compared to what they would have experienced had they not dropped out. $^{10}$

\section{$4 \quad$ How do dropout rates compare between countries?}

Table 1 provides self-reported tertiary dropout rates by education level of education and country. As a reminder, the percentage derives from expressing the number of individuals reporting dropout experience as a share of the total number of adults who enrolled in tertiary education. The variation between countries is huge. In Italy, every third adult who enrolled in tertiary education dropped out compared to just every sixth adult in Germany and the UK. Countries like Poland, Sweden and Ireland meet the country average with every fifth person having dropped out of tertiary education.

How does this self-reported PIAAC measure compare to the OECD measure described above? Figure 1 provides a scatter plot of both measures for 15 countries covered in both sources. It is important to bear in mind that the dropout estimate used in this paper spans over experience during adults' lifetime compared to the OECD estimate of student non-completion within a small number of years after tertiary education enrolment. As a result, it might therefore surprise that for almost half of our countries the rank order and size of measure are fairly similar (France, Denmark, Finland, Belgium, Czech Republic, Spain and the Netherlands). However, the correlation coefficient between measures is zero if the OECD countries Korea and Japan are not taken into account and increases to 0.41 with these two countries.

The OECD measure itself changes for some countries considerably between years $^{11}$. I.e. in the 2013 OECD report the UK measure is 7 percentage points (20 per cent) lower than in the 2010 report while for the Slovak Republic it increased by 8 percentage points. For both countries, cross-sectional data were used.

Figure 1 shows that 11 out of the 15 countries are positioned below the diagonal line, indicating that the OECD dropout estimate is greater than the PIAAC measure. This is not surprising given that the OECD estimate counts all those students as dropouts who did not complete within a short time interval ' $i$ '. Sweden is the most notable example; for this country the OECD report (2013) states that tertiary students who do not intend to graduate are counted as dropouts.

\footnotetext{
${ }^{10}$ In contrast, the average treatment effect (ATE) is an average partial effect for a binary variable for a randomly drawn person from the population.

${ }^{11}$ OECD tertiary dropout rates for the 16 countries covered in both Education at a Glance reports (2010 and 2013) are correlated with 0.93 .
} 
It is a common feature of most research on tertiary dropout students to investigate dropout behaviour only to the time point the student actually drops out: the predominant part of research does not examine whether tertiary dropout students re-enter tertiary education and complete a degree. This is very different to research on school attainment studies, where generally dropout students are defined as only those who did not postpone completion of their school degree but permanently decided to drop out.

For judging about the efficiency of the tertiary system as well as on reinforcement of educational inequalities, there is a clear rational to define also tertiary dropout only on the basis of permanent dropout. How does the country ranking discussed above change with this definition?

There are several interesting results to note. First, on average across all countries, 38 per cent of tertiary dropouts attain a tertiary education degree (last column in Table 1, weighted by countries). This goes in line with Stratton et al. (2007) who show that $40 \%$ of all first year attrition is temporary in the US. For many adults tertiary dropout is therefore not a permanent decision. While on average across countries 22 per cent of adults experienced drop out, only 14 per cent of adults did so without having completed a degree.

Remarkable is the huge variation of the percentage of dropouts completing tertiary education ranging from just 6 per cent in Italy to 58 per cent in Denmark and Sweden (last column of Table 1). If countries were to be reordered on dropout of upper secondary educated only, Scandinavian countries would improve their ranking considerably. These results indicate that it is sensible to differentiate between tertiary and upper secondary educated dropouts which will be done in the remainder of the paper.

While this paper does not aim at explaining high tertiary dropout figures there are several explanations that could be employed depending on how countries tertiary education systems and labour markets are classified.

A differentiation of countries by the extent of fees students need to pay for entry into tertiary education has shown not to be helpful in explaining dropout figures (OECD 2013a).

It could be argued that education systems are more efficient if they have high student intake, so that dropout rates become smaller. At the same time, those countries with higher university admission deal on average also with students 
coming from higher parental background compared to countries with low tertiary completion. Since at the individual level higher parental background is associated with lower student drop we might assume so similarly at the macro level of countries: the higher tertiary completion in a country, the higher students' background and the hence the lower a countries student dropout. However, while Figure 2 indicates a negative correlation (-0.54) between per cent of the population having attained tertiary education and student drop out this correlation coefficient is mainly determined by the position of Italy and the Czech Republic.

Another classification of education systems could be on the basis of how flexible entry and exit into tertiary education is. The decision of withdrawal from tertiary education is easier, if re-entry is possible. A proxy for flexibility could be the per cent of tertiary dropouts who complete their degree after having dropped out. However, Figure 3 shows that any possible association between percentage of dropout students and the per cent among those who later on in their life re-enter and attain tertiary education is due to the outlier position of Italy.

Most successful in explaining variation between countries regarding dropout rate might be differences in admission policies. In some European Countries like Italy, Netherlands and Belgium a school leaving certificate is generally sufficient for being admitted to study at university (NCIHE 1997). The student population within these countries includes a spectrum of high and low ability students. This is quite different to the UK which has a highly selective system with fixed quotas and varying admission policies based on achievement for different courses. Given that upper secondary school achievement is highly correlated with university dropout, dropout rates are lower in countries that use a numerus clausus system of ability selectivity.

Small sample sizes of dropouts make it difficult to separate out different cohorts; however it is possible to divide the sample into two age groups: 25 to 44 and 45 to 64 year olds. Figure 4 sorts countries by changes in dropout rates over time. In seven out of 15 countries differences for both age groups are significant. In Italy, Denmark and Spain dropout decreased for the younger age cohort while it increased in the Czech Republic, Belgium, Finland and Norway. In most other countries changes in dropout rates are relatively small in size. 


\section{$5 \quad$ Who are dropout students?}

Given that girls' upper secondary educational achievement is generally higher than that of boys and that literature stipulates an existing correlation of ability with university drop out, it is not surprising that more men than women drop out of tertiary education. Indeed, OECD (2008) discusses the pattern of increasingly higher female tertiary completion rates even though gender differences vary by subject area studied. However, the consistency of this gender pattern in dropout rates across countries and the extent is astonishing. Table 2 shows that in Poland almost twice as many men than women withdraw from tertiary education. About a third more men than women drop out in the Scandinavian countries Finland, Norway, Sweden and Denmark. In nine out of the 15 countries, dropout rates for men are at least 5 percentage points higher than that of women.

Besides gender, socio-economic background is associated with tertiary dropout. PIAAC information on adults' family background is mainly limited to parental education. ${ }^{12}$ Table 3 provides the share of individuals having at least one parent with tertiary education by education and dropout status. For example, among tertiary educated 68 per cent of dropouts but only 50 per cent of non-dropouts have at least one parent with a tertiary degree in Germany. Percentage points are printed bold if differences between equally educated dropouts and counterparts are significant at the 1 per cent level. Not surprisingly, upper secondary educated dropouts have a higher parental background in 14 out of 15 countries, which reflects the self-selection of individuals into tertiary education. Surprising however is that tertiary educated dropouts have a higher socio-economic background in 8 countries compared to equally educated. Given that dropouts generally have lower socio-economic background than other individuals attending tertiary education, this results shows that only those dropouts manage to reenrol and complete who have the most advantageous background within the group of individuals having withdrawn.

This pattern is also confirmed once we focus on cognitive skills. Table 4 shows that in 8 out of 15 countries again the tertiary educated dropouts have

\footnotetext{
${ }^{12}$ Information is also available on immigrant status, i.e. whether both parents and individual were born abroad. However, taking into account that tertiary drop out students are on average about 7 per cent of the sample and immigrant students $8.5 \%$, the sample size is small for investigating a significant 'effect' of immigrant status on drop out. Results indicate that in Spain immigrant students are more likely to drop out. In other countries the per cent point differences are similar, but sample sizes too small to claim that differences are significant.
} 
significant higher skills than equally educated counterparts. Not surprisingly, also upper secondary educated dropouts fare better than those who never enrolled into tertiary education. This confirms the positive selection of dropouts within the education category they belong to. Since cognitive skills and parental background is not only positively related to dropout status but as well to labour market chances it is vital to take these characteristics into account for estimating the 'effect' of dropout on career progression.

\section{Labour market success of adults with tertiary dropout experience}

Given their higher cognitive skills and socio-economic background, we would expect employment chances to be also better for adults with dropout experience. As Table 5 shows, this is true for upper secondary educated adults. In Italy and Ireland dropouts are more than 10 percentage points likely to be employed than other upper secondary educated. For almost all countries, this tendency applies even though differences are considerably smaller and sometimes not significant. However, tertiary educated dropouts' higher skill and socio-economic background does generally not increase their employment chances compared to equally educated with the UK being a notable exception. In France and Denmark, dropouts face even lower employment than other tertiary educated. This indicates that in contrast to upper secondary educated, tertiary educated dropouts cannot exploit their advantageous characteristics compared to equally educated adults.

The same picture emerges once we look at career progression in terms of reaching professional positions in the labour market in Table 6. Among the upper secondary educated, dropouts are between 5 (France and Italy) and 17 percentage points (Czech Republic, Slovak Republic and Netherlands) more likely to have gained a prestigious job than individuals who did not enrol in tertiary education. In nine out of twelve European countries, for which the job position variable ISCO-88 was collected, the differences in career progression are significantly in favour of dropouts. This is in contrast to tertiary educated, where dropouts fare worse than their counterparts in seven out of 12 countries, however only in one country significantly (Belgium). Only in the Czech Republic and Spain (the latter with a significance level of $10 \%$ ) there is an indication of an advantage of dropouts.

In sum, unconditional on background characteristics withdrawal experience does not penalise, but neither favours tertiary educated in terms of labour market 
chances but it does increase chances for the upper secondary educated. As discussed above, we can assume that a considerable part of the differences we find between adults with and without dropout experience is due to a non-random selection of adults into dropout status. We showed that dropouts are more likely than other adults to exhibit those individual characteristics that are positively linked to better labour market chances.

In order to take selection into account, we first apply logistic regression analysis. We include an explanatory variable that is equal to 1 if the person has dropout experience and tertiary education (otherwise 0 ) and a variable that is equal to 1 if the person has dropout experience and just upper secondary education. ${ }^{13}$ Dependent variables are the variables already investigated unconditionally in Tables 5 and 6: being in employment and holding a prestigious job position.

Table 7 presents regression coefficients for the two explanatory variables tertiary and secondary dropouts only. For both dependent variables three models were run: one model controlling solely for educational background (using a dummy on tertiary education), a second model controlling for other individual characteristics (gender, migration background, young children in the household, whether the individual has a partner, whether the partner is employed, highest parental education, age and age square) and a third model that adds cognitive numeracy and literacy skills ${ }^{14}$ as well as work experience expressed in years.

Regarding logistic regression results coefficients of covariates (not presented) were in the expected direction. (Full regression results can be obtained from the author.) The higher the education the lower was the risk of being not employed and the higher the chance of holding a professional position. Only in France and the Netherlands, being a migrant significantly increased the risk of being not in employment and lowered chances of being a manager. For all countries, having a child at 6 years old or below decreased the chance of being in employment sizably and significantly. Conditional on having a partner, having an employed partner either reduced the risk of not being employed or increased the probability of being a manager or both significantly in all countries with the exception of the Czech

\footnotetext{
${ }^{13}$ We would have received the same results if we had used a binary variable on dropout and an interaction of the dropout variable with tertiary education.

${ }^{14}$ Skills are used as proxy on ability before university dropout. Since skills are positively related to our measures of labour market progression for all countries, it can be shown that the measurement error in our proxy will lead to a downwards bias of the estimated 'effect'. (Angrist and Pischke 2008, p. 50)
} 
Republic. Conditional on other factors, individuals with a parent holding tertiary education were often significantly more likely to be a manager and sometimes more likely to be not employed. Older age and higher number of years work experience were associated with a higher probability of not being in employment. Higher cognitive abilities were generally related to higher probability of being a manager and lower probability of not working. While for all countries women had a higher probability of not working conditional on the factors discussed above, the probability of being a manager differed. In Poland and the Slovak Republic women had a higher, in France, the Netherlands and the UK women had a lower chance of being a manger and in the other countries the coefficient was not significant.

Regression coefficients for Model 1 in Table 7 reflect unconditional results presented in Tables 5 and 6. Changes of the dropout coefficient conditional on other individual characteristics (Model 2) as well as work experience and skills (Model 3) reflect the selection into the group of dropouts. For upper secondary educated, unconditional employment probabilities were higher for dropouts in six out of 15 countries. Conditional on socio-economic background dropout status matters only in 3 countries, whereby once in addition skills and work experience are controlled for dropouts fare better only in the two countries Italy and Ireland.

In terms of holding prestigious labour market positions, conditioning does lead to smaller coefficients compared to the unconditional coefficient presented in Model 1. However, in seven countries out of twelve (Belgium, Czech Republic, Denmark, France, the Netherlands, Poland and Slovak Republic) dropouts are still more likely to obtain more prestigious jobs than other upper secondary educated adults. Interestingly, in the three countries (Germany, Italy and the UK) in which dropout status falls into insignificance this seems to be mainly due to the conditioning on skills and labour market experience. ${ }^{15}$

For the tertiary educated, coefficients are generally not significant. They do fare better in employment in the UK, but worse in Denmark and most other countries. In terms of professional jobs, about half of the countries' coefficients indicate a disadvantage and the other half an advantage of tertiary dropouts. It is interesting to note, that only conditional on skills tertiary dropouts fare significantly and considerably worse in Germany regarding their job prospects. For some countries

\footnotetext{
${ }^{15}$ This is of importance showing that a study using a similar design but not having data on cognitive skills would not be able to rely on the conditional independence assumption.
} 
however, conditioning on labour market experience, which is likely to be lower for dropouts, leads to a decrease in the regression coefficient.

Since the interpretation of logistic regression coefficients is not straight forward, Model 3 is employed in order to calculate predicted probabilities for having attained a prestigious job or being employed by education and dropout status conditional on individual characteristics which are set to the mean of the country sample. The percent point difference of the predicted probabilities between adults with and without dropout experience but with the same level of education is provided in Table 8 columns 1 (for being in employment) and 4 (for high professions). sys Given the regression assumptions of linearity and the problem of common support as described in Section 3, we use PSM on two separate samples: tertiary educated and upper secondary educated. We estimate the propensity score of dropout by taking the same covariates used for the logistic regression design into account. While, as expected, the propensity score for dropouts is higher than for non-dropouts, we generally find that common support is given, so that only for some countries a handful of people are excluded from the matching process. Generally, matching quality is for all countries and with both matching method, nearestneighbour matching with caliper and Kernel Epanechnikov matching, high. However, in most cases Kernel matching works better given the remaining average mean bias as well as the higher efficiency of the matching procedure. The disadvantage of Kernel however is that individuals with very different propensity scores compared to a treatment person can impact on the results. Table 8 presents percent point differences between dropouts and equally educated individuals by dependent variable (professional position and being in employment) and matching methods in columns 2, 3, 5 and 6. Cells showing significant differences are shaded. The analysis is conducted for each outcome variable and country separately.

Are tertiary educated with tertiary dropout experience penalised in terms of labour market success? Percent point differences in employment and professional status between tertiary educated adults with and without dropout experience (upper row for each country) are generally not significant for the countries examined. This is true for both, logistic regression and PSM results. For the UK, PSM with kernel matching supports the previous results of the logistic regression indicating that tertiary educated dropouts have higher employment chances. In Denmark tertiaries' disadvantage is confirmed only by PSM with calliper matching. 
Tertiary educated dropouts experience a more than 10 percentage point smaller chances to obtain a professional job than equally educated in Belgium and Germany. In other countries they do not fare better besides in Spain.

Do tertiary dropouts who never completed tertiary education gain from tertiary enrolment? In terms of employment, upper secondary dropout adults have an about 5 to 10 percentage point higher probability being employed in Italy and Belgium consistently across different methods. In addition, there is a general trend that the percent point differences are positive across countries indicating an advantage for dropouts.

In six out of twelve countries adults having withdrawn from tertiary education are more likely to get into professional positions compared to other upper secondary educated counterparts. Given that sample sizes are small for dropouts, effects need to be big in size to be significant. In the Netherlands, 15 to 18 percent points more dropouts than other equally educated are in prestigious positions depending on the estimation method applied. In the Czech Republic the percent point difference lies between 11 and 14, in Denmark between 10 and 13 and in Poland between 6 and 10 percentage points. In France, Germany and Italy the percent point difference is around 4, however not significant.

In sum, once employment and prestigious positions are concerned tertiary educated dropouts are generally not penalised in comparison to other tertiary educated (with the exception of Belgium and Germany in terms of prestigious jobs). Upper secondary educated dropouts have no significant advantage to equally educated in gaining professional positions in the three Southern countries France, Italy and Spain and the UK and Norway but benefit from a sizable advantage in the three Eastern European countries Poland, Czech and Slovak Republic as well as in the Northern countries Denmark and the Netherlands and Belgium. We checked whether this advantage could be related to the number of years spent in tertiary education, which we proxied probably relatively well for about $75 \%$ of dropouts ${ }^{16}$ by taking the difference between age of dropping out of tertiary education and age having completed the highest degree. For the Netherlands and employing logistic regression, this variable was highly significant and indicated a 10 percentage point

\footnotetext{
${ }^{16}$ For 75 percent of dropouts the difference between age of dropout and age receiving highest degree is 6 years or less.
} 
increase of being a manager for each year in tertiary education. In the other countries, this variable was not of importance.

It is difficult to explain country position without engaging in detail into the linkage between labour market regulations and educational system of each country, which is not the aim of this paper. Nevertheless, as discussed above, signalling theory predicts an employment advantage for dropouts in internal labour markets like Italy, Spain and France. For Italy we find higher employment chances for dropouts, however not for France and Spain. At the same time, progression within the labour market is not better for dropouts in these three countries. This might be explained by the fact that a considerable part of training takes place within a firm in internal labour markets, so that knowledge acquired during tertiary education attendance does not improve progression chances. In the relative flexible labour market of the UK for which human capital theory would predict an advantage of dropouts in terms of labour market entry and progression only tertiary dropouts' gain better employment chances.

Labour market structures cannot help explain the positive impact of dropout among upper secondary educated on career progression in the Czech Republic, Poland, the Netherlands and Denmark, especially given that in Norway dropouts are not in an advantage. Instead of focusing on labour markets alone, it might well be assumed that the vocational structure of the education system is of importance. We hypothesised above that dropouts outperform other upper secondary educated in countries with a high vocational pathway within the school systems. This is indeed the case in the Netherlands, the Czech Republic and Poland where tertiary dropouts fare so much better in acquiring professional jobs. However, we would equally suspect to find a similar advantage for dropouts in Italy as another country with a school-based vocational pathway. In addition, Denmark, where dropouts fare better too, is relatively similar to the UK in its distribution of upper secondary students to general and vocational pathways (OECD 2000, Table 2.2), but differs considerably in terms of dropouts' career advantages.

Given the great importance of the gender dummy in the models as well as the clearly lower dropout rate for females, we also used female dropout interaction variables within our logistic regression modelling. In France and Poland the risk of not being in employment was higher for female upper secondary educated dropouts 
compared to males. For all other countries, the female interaction coefficient was not significant.

\section{Conclusion}

Tertiary dropout is generally discussed as a negative outcome in terms of wasting educational resources at the individual and societal level. This view contradicts economic theories: i.e. the human capital theory predicts that with or without degree every year in tertiary education is a gain for labour market chances. The signalling theory suggests that even without degree dropouts are better off than equally educated. Only credentialism predicts that tertiary dropouts do not gain from enrolment. Once the focus is on education systems, we also hypothesised that dropout experience might improve labour market chances in these countries, where vocational pathways are overrepresented during upper secondary schooling thereby decreasing their value compared to general education. Hence, from a theoretical point of view hypotheses predicting an advantage of adults with dropout experience prevail.

Surprisingly however, there is a lack of literature that examines tertiary dropouts' career prospects. Using PIAAC data on adults' self-reported withdrawal from tertiary education this paper therefore examined whether dropout is indeed just a negative experience without any beneficial impact on employment chances and professional status in an international context.

The self-reported measure in this paper yields similar results to published OECD dropout figures based on student cohorts for 7 out of 15 countries.

In contrast to a considerable part of literature treating dropout to be a permanent decision, the paper shows that on average across countries almost 40 per cent of tertiary dropouts acquire tertiary education later in their life.

Withdrawal from tertiary education is highest in Italy and lowest in the UK and Germany. Scandinavian countries display low dropout once we focus only on those tertiary dropouts who did not attain tertiary education later in their life.

For almost all EU countries examined women drop out less than men whereby percentage point differences are huge between genders in the countries Poland, Spain, Czech Republic, Italy and Finland. Tertiary educated dropouts have higher socio-economic background and cognitive skills than equally educated counterparts. The same is true for upper secondary educated. Given the positive 
association between skills and socio-economic background with labour market chances, unconditional results on labour market success mask that dropouts are a positively selected group among individuals holding the same educational degree.

Employing logistic regression analysis and propensity score matching the study compared the probability of being employed or in professional jobs between dropouts and equally educated adults conditional on socio-economic and demographic background and cognitive skills. We found interesting common country patterns. In general, tertiary educated dropouts have similar chances of employment and progressing to professional positions as non-dropouts. Only in Germany and Belgium they seem to be penalised with lower prospects of obtaining high level positions in the labour market.

Once we focused on adults with upper secondary education, logistic regression and propensity score matching results showed consistently that dropouts are in more favourable positions than their counterparts in terms of holding professional positions in half the countries examined. There is no clear disadvantage for dropouts in terms of employment chances. However, in general country patterns are difficult to explain.

In sum and in contrast to the negative connotation attached to tertiary dropout in retention studies results presented here show generally that dropout can very well be a 'positive' indicator in the labour market. This is first due to the fact that the dropout decision is in many cases not a permanent one which is largely not taken into account in existing research. Those dropout adults who obtained their degree later fare similar to tertiary educated who never experienced dropout. Second, for all countries examined and conditional on demographic, socio-economic background and cognitive skills on average those individuals who attended but dropped out of tertiary education fare often better and never worse in terms of career progression than those who never enrolled. This result asks for a revision of the purely negative view associated with tertiary dropout.

Future research could link countries' labour market regulations with their educational systems in order to unveil mechanisms for dropouts' success and use a multi-dimensional measure of career pathways. 


\section{Tables and Figures}

Table 1: 25 to 64 year old adults who report tertiary dropout as per cent of adults ever enrolled in tertiary education by education attained

\begin{tabular}{|c|c|c|c|c|c|}
\hline & \multicolumn{2}{|c|}{ Total drop out } & \multirow{2}{*}{$\begin{array}{c}\text { Upper } \\
\text { secondary } \\
\text { educated } \\
\%\end{array}$} & \multirow{2}{*}{$\begin{array}{c}\text { Tertiary } \\
\text { educat } \\
\text { ed } \\
\%\end{array}$} & \multirow{2}{*}{$\begin{array}{r}\% \text { of dropouts } \\
\text { holding tertiary } \\
\text { education }\end{array}$} \\
\hline & $\%$ & se & & & \\
\hline Italy & 34.1 & 1.3 & 32.0 & 2.1 & 6.1 \\
\hline Netherlands & 28.3 & 1.0 & 15.4 & 12.9 & 45.6 \\
\hline Czech Republic & 27.8 & 1.6 & 18.9 & 8.9 & 31.9 \\
\hline Spain & 24.2 & 1.1 & 14.9 & 9.3 & 38.5 \\
\hline Denmark & 23.5 & 0.9 & 9.9 & 13.6 & 57.9 \\
\hline Belgium & 22.8 & 1.1 & 12.8 & 10.0 & 43.9 \\
\hline Ireland & 21.5 & 1.2 & 13.3 & 8.2 & 38.1 \\
\hline Sweden & 21.2 & 1.2 & 8.9 & 12.3 & 58.2 \\
\hline Poland & 20.0 & 1.2 & 12.6 & 7.4 & 37.2 \\
\hline Slovak Republic & 18.6 & 1.5 & 16.0 & 2.6 & 14.1 \\
\hline Finland & 18.5 & 0.9 & 10.1 & 8.5 & 45.7 \\
\hline France & 17.9 & 0.8 & 9.3 & 8.6 & 47.9 \\
\hline Norway & 17.4 & 0.9 & 8.1 & 9.2 & 53.1 \\
\hline United Kingdom & 16.3 & 0.9 & 10.8 & 5.5 & 33.8 \\
\hline Germany & 14.7 & 0.9 & 9.2 & 5.5 & 37.7 \\
\hline All & 21.8 & 0.5 & 13.5 & 8.3 & 38.2 \\
\hline
\end{tabular}

Note: countries are ordered by per cent of adults ever enrolled in tertiary education reporting tertiary dropout. Individual with less than upper secondary education, in education during the interview or having attained tertiary education abroad are excluded. Adults reporting tertiary dropout only after having already obtained a tertiary degree are not considered to be tertiary dropouts. 
Table 2: Adults reporting tertiary dropout expressed as percentage of all adults having attended tertiary education by gender

\begin{tabular}{lccr} 
& Women & Men & \\
\hline Poland & 14.9 & 26.3 & $\mathbf{- 1 1 . 4}$ \\
Italy & 29.1 & 39.7 & $\mathbf{- 1 0 . 6}$ \\
Finland & 14.6 & 23.6 & $\mathbf{- 9 . 0}$ \\
Norway & 13.8 & 21.1 & $\mathbf{- 7 . 3}$ \\
Sweden & 18.0 & 25.1 & $\mathbf{- 7 . 1}$ \\
\hline Denmark & 20.4 & 27.2 & $\mathbf{- 6 . 8}$ \\
Spain & 21.2 & 27.3 & $\mathbf{- 6 . 1}$ \\
Czech Republic & 24.6 & 30.7 & $\mathbf{- 6 . 1}$ \\
Slovak Republic & 15.9 & 21.6 & $\mathbf{- 5 . 7}$ \\
Belgium & 20.5 & 25.2 & $\mathbf{- 4 . 7}$ \\
\hline Ireland & 19.5 & 23.9 & $\mathbf{- 4 . 4}$ \\
Netherlands & 26.2 & 30.2 & $\mathbf{- 4 . 0}$ \\
Germany & 12.4 & 16.4 & $\mathbf{- 3 . 9}$ \\
France & 18.0 & 17.8 & 0.2 \\
United Kingdom & 16.9 & 15.6 & 1.4 \\
\hline
\end{tabular}

Note: bold printed figures indicate a significant difference in dropout rates between women and men at the 1 per cent level. 
Table 3: Per cent individuals having at least one parent with tertiary education by education and dropout status

\begin{tabular}{lrrr|rrr} 
& \multicolumn{3}{c|}{ Tertiary educated } & \multicolumn{3}{c}{ Upper secondary educated } \\
Country & $\begin{array}{r}\text { Dever } \\
\text { Drop }\end{array}$ & $\begin{array}{r}\text { Drop } \\
\text { droped } \\
\text { out }\end{array}$ & Difference & Not & $\begin{array}{r}\text { enrolled } \\
\text { tertiary }\end{array}$ & Difference \\
\hline Norway & 59.2 & 43.6 & $\mathbf{1 5 . 6}$ & 45.4 & 18.4 & $\mathbf{2 7 . 0}$ \\
Belgium & 49.1 & 37.6 & $\mathbf{1 1 . 5}$ & 32.6 & 10.1 & $\mathbf{2 2 . 5}$ \\
Germany & 67.7 & 50.0 & $\mathbf{1 7 . 7}$ & 43.6 & 21.6 & $\mathbf{2 2 . 0}$ \\
Ireland & 36.7 & 35.0 & 1.7 & 30.2 & 9.3 & $\mathbf{2 0 . 9}$ \\
Sweden & 61.9 & 45.6 & $\mathbf{1 6 . 3}$ & 44.8 & 24.2 & $\mathbf{2 0 . 6}$ \\
\hline Netherlands & 41.3 & 36.1 & 5.2 & 30.0 & 12.1 & $\mathbf{1 7 . 9}$ \\
France & 44.6 & 34.0 & $\mathbf{1 0 . 6}$ & 21.1 & 6.3 & $\mathbf{1 4 . 8}$ \\
Czech Republic & 46.5 & 36.6 & 9.9 & 21.1 & 6.8 & $\mathbf{1 4 . 3}$ \\
Slovak Republic & 35.4 & 31.7 & 3.7 & 18.4 & 4.2 & $\mathbf{1 4 . 2}$ \\
Finland & 32.0 & 20.6 & $\mathbf{1 1 . 4}$ & 21.1 & 8.2 & $\mathbf{1 2 . 9}$ \\
\hline United Kingdom & 42.8 & 38.5 & 4.3 & 23.2 & 10.6 & $\mathbf{1 2 . 6}$ \\
Denmark & 52.0 & 43.4 & $\mathbf{8 . 6}$ & 26.4 & 15.9 & $\mathbf{1 0 . 5}$ \\
Poland & 28.2 & 28.5 & -0.3 & 10.3 & 4.2 & $\mathbf{6 . 1}$ \\
Italy & 24.0 & 21.2 & 2.8 & 7.5 & 2.5 & $\mathbf{5 . 0}$ \\
Spain & 31.6 & 22.1 & 9.5 & 11.9 & 8.5 & 3.4 \\
\hline Average & 41.8 & 33.9 & $\mathbf{7 . 9}$ & 24.6 & 10.1 & $\mathbf{1 4 . 5}$
\end{tabular}

Note: bold printed figures indicate significance at the $1 \%$ level. 
Table 4: Cognitive skill differences in literacy between adults with and without dropout experience by education

\begin{tabular}{|c|c|c|c|c|c|c|}
\hline \multirow[b]{2}{*}{ Country } & \multicolumn{3}{|c|}{$\begin{array}{c}\text { Tertiary educated } \\
\text { Never }\end{array}$} & \multicolumn{3}{|c|}{$\begin{array}{c}\text { Upper secondary educated } \\
\text { Not }\end{array}$} \\
\hline & Drop out & $\begin{array}{r}\text { dropped } \\
\text { out }\end{array}$ & Difference & Drop out & $\begin{array}{r}\text { enrolled } \\
\text { tertiary }\end{array}$ & Difference \\
\hline Czech Republic & 308 & 301 & 6 & 297 & 266 & 31 \\
\hline Denmark & 300 & 292 & 8 & 283 & 260 & 22 \\
\hline Finland & 323 & 307 & 16 & 296 & 271 & 25 \\
\hline France & 300 & 293 & 6 & 285 & 256 & 29 \\
\hline Germany & 315 & 292 & 23 & 295 & 259 & 36 \\
\hline Ireland & 299 & 291 & 7 & 282 & 263 & 19 \\
\hline Italy & 290 & 280 & 10 & 276 & 259 & 17 \\
\hline Netherlands & 321 & 308 & 13 & 305 & 278 & 27 \\
\hline Belgium & 316 & 301 & 15 & 292 & 262 & 30 \\
\hline Norway & 313 & 301 & 13 & 283 & 269 & 14 \\
\hline Poland & 295 & 296 & -1 & 276 & 252 & 24 \\
\hline Slovak Republic & 305 & 295 & 10 & 288 & 272 & 16 \\
\hline Spain & 291 & 278 & 12 & 264 & 253 & 12 \\
\hline Sweden & 321 & 305 & 16 & 298 & 272 & 27 \\
\hline United Kingdom & 304 & 294 & 9 & 292 & 265 & 27 \\
\hline Average & 306 & 296 & 10 & 287 & 264 & 23 \\
\hline
\end{tabular}

Note: bold printed figures indicate significance at the $1 \%$ level. 
Table 5: Per cent of working age adults being in employment by tertiary dropout status, tertiary and upper secondary education and per cent point differences

\begin{tabular}{|c|c|c|c|c|c|c|}
\hline & $\begin{array}{c}\text { Tertiary } \\
\text { Drop } \\
\text { out }\end{array}$ & $\begin{array}{l}\text { educated } \\
\text { Never } \\
\text { dropped } \\
\text { out }\end{array}$ & Difference & $\begin{array}{r}\text { Upper s } \\
\text { Drop } \\
\text { out }\end{array}$ & $\begin{array}{r}\text { econdary } \\
\text { Not } \\
\text { enrolled } \\
\text { tertiary }\end{array}$ & educated \\
\hline Italy & 79.7 & 83.3 & -3.6 & 83.7 & 69.3 & 14.4 \\
\hline Ireland & 85.6 & 82.6 & 3.0 & 76.8 & 65.4 & 11.4 \\
\hline Belgium & 92.4 & 89.9 & 2.5 & 87.1 & 78.3 & 8.8 \\
\hline Czech Republic & 84.4 & 84.9 & -0.5 & 82.6 & 74.0 & 8.6 \\
\hline Poland & 92.7 & 87.8 & 4.9 & 70.5 & 62.1 & 8.4 \\
\hline France & 79.0 & 86.2 & -7.2 & 79.5 & 73.2 & 6.3 \\
\hline Slovak Republic & 85.3 & 86.8 & -1.5 & 74.8 & 69.3 & 5.5 \\
\hline Sweden & 95.1 & 92.2 & 2.9 & 88.7 & 85.0 & 3.7 \\
\hline Finland & 88.5 & 88.5 & 0.0 & 79.5 & 76.5 & 3.0 \\
\hline Spain & 77.7 & 80.2 & -2.5 & 69.3 & 67.0 & 2.3 \\
\hline Netherlands & 87.8 & 88.4 & -0.6 & 83.6 & 81.5 & 2.1 \\
\hline United Kingdom & 92.0 & 83.7 & 8.3 & 75.5 & 74.1 & 1.4 \\
\hline Norway & 94.3 & 92.2 & 2.1 & 82.3 & 83.3 & -1.0 \\
\hline Germany & 91.4 & 90.0 & 1.4 & 76.8 & 80.3 & -3.5 \\
\hline Denmark & 84.3 & 89.0 & -4.7 & 70.8 & 77.9 & -7.1 \\
\hline
\end{tabular}

Note: bold figures for percentage point differences are significant at the 5 per cent level. Countries are ordered by the size of the per cent point differences of employment between upper secondary educated with and without tertiary dropout experience. 
Table 6: Per cent employed working in professional positions by tertiary dropout status, tertiary and upper secondary education and per cent point differences

\begin{tabular}{|c|c|c|c|c|c|c|}
\hline & \multicolumn{3}{|c|}{ Tertiary educated } & \multicolumn{3}{|c|}{ Upper secondary educated } \\
\hline & Drop out & $\begin{array}{r}\text { Never } \\
\text { dropped } \\
\text { out }\end{array}$ & Difference & Drop out & $\begin{array}{r}\text { Not } \\
\text { enrolled } \\
\text { tertiary }\end{array}$ & Difference \\
\hline Netherlands & 70.5 & 69.8 & 0.7 & 39.1 & 21.2 & 17.9 \\
\hline Slovak Republic & 69.3 & 66.2 & 3.1 & 31.2 & 13.9 & 17.3 \\
\hline Czech Republic & 67.4 & 57.3 & 10.1 & 25.5 & 8.8 & 16.7 \\
\hline Denmark & 65.5 & 66.3 & -0.8 & 29.2 & 13.7 & 15.5 \\
\hline Belgium & 54.4 & 64.5 & -10.1 & 25.8 & 11.1 & 14.7 \\
\hline Germany & 49.2 & 55.1 & -5.9 & 13.5 & 3.8 & 9.7 \\
\hline Poland & 59.2 & 61.8 & -2.6 & 16.3 & 8.2 & 8.1 \\
\hline United Kingdom & 48.3 & 50.2 & -1.9 & 22.2 & 15.1 & 7.1 \\
\hline Italy & 54.4 & 57.0 & -2.6 & 15.8 & 10.1 & 5.7 \\
\hline France & 51.4 & 52.4 & -1.0 & 12.1 & 6.5 & 5.6 \\
\hline Norway & 62.9 & 61.3 & 1.6 & 16.1 & 13.9 & 2.2 \\
\hline Spain & 58.4 & 48.3 & 10.1 & 14 & 13.9 & 0.1 \\
\hline
\end{tabular}

Note: bold figures of percentage point differences denote significance at the 5 per cent level. Professional positions refer to individuals' current work, as a consequence unemployed or people out of the labour force are excluded. Countries are ordered by the size of the per cent point differences of being in professional jobs between upper secondary educated with and without tertiary dropout experience. 
Table 7: Selection of logistic regression coefficients for adults with dropout experience by education

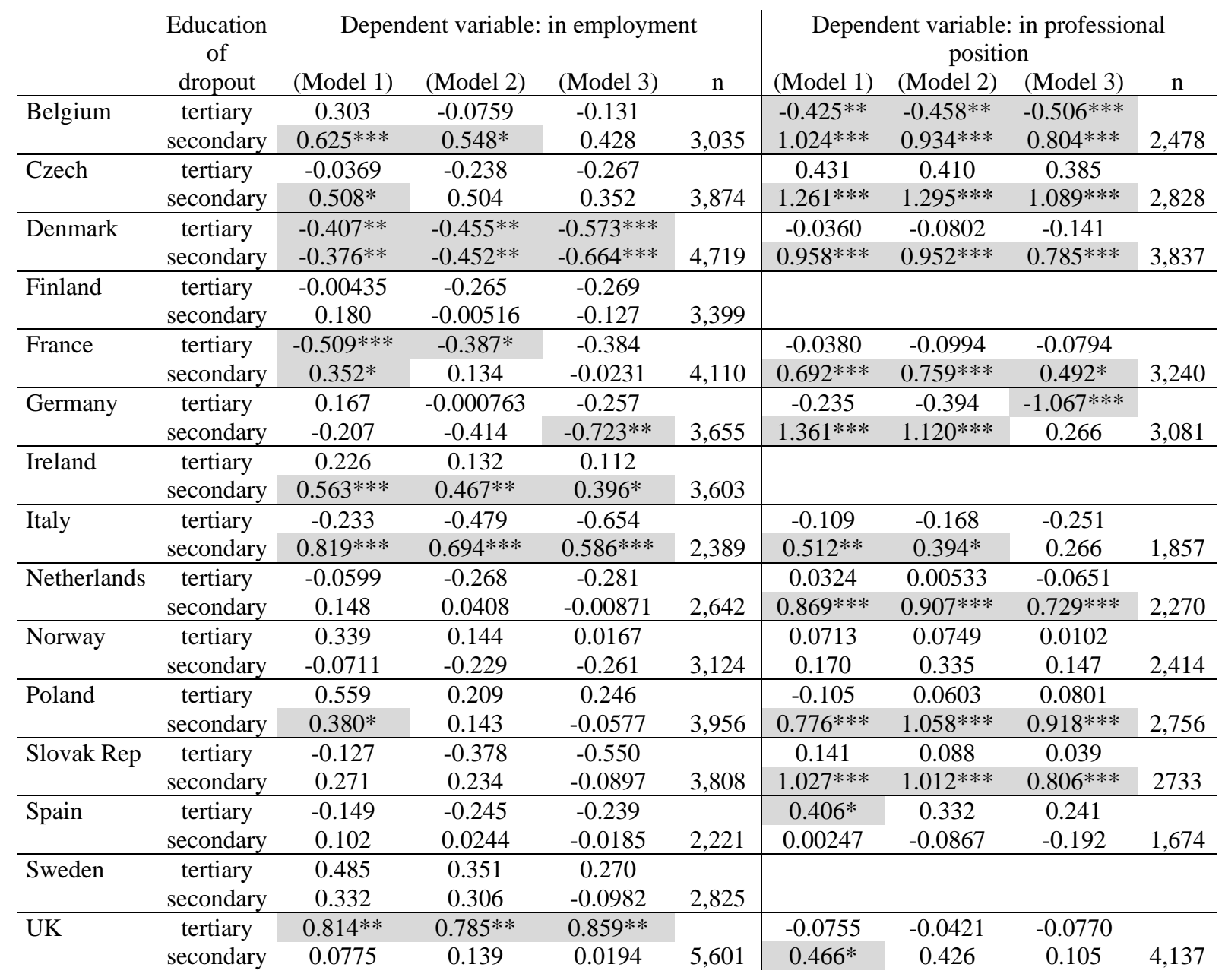

Note: Model 1 controls only for educational background, Model 2 controls for gender, migration background, young children living in the household, whether individual lives in a partnership, whether the partner is employed, highest parental education, age and age square. Model 3 takes work experience measured in years and cognitive ability in terms of numeracy and literacy into account. ** denotes $p<0.01,{ }^{* \star} p<0.05$ and ${ }^{*} p<0.1$. Grey shaded cells show significance of regression coefficient. 
Table 8: Percent point difference for employment and holding professional positions between dropouts and non-dropouts by education and counterfactual impact evaluation method applied

\begin{tabular}{|c|c|c|c|c|c|c|c|c|c|c|c|c|}
\hline \multirow{4}{*}{ Belgium } & \multirow{4}{*}{$\begin{array}{c}\begin{array}{c}\text { Education } \\
\text { of } \\
\text { dropout }\end{array} \\
\begin{array}{c}\text { tertiary } \\
\text { secondary }\end{array}\end{array}$} & \multicolumn{5}{|c|}{$\begin{array}{l}\text { Dependent variable: } \\
\text { in employment }\end{array}$} & \multicolumn{6}{|c|}{$\begin{array}{c}\text { Dependent variable: in professional } \\
\text { position }\end{array}$} \\
\hline & & \multicolumn{2}{|c|}{$\begin{array}{l}\text { Logistic } \\
\text { regression }\end{array}$} & $\begin{array}{l}\text { PSM } \\
\text { caliper }\end{array}$ & \multicolumn{2}{|c|}{$\begin{array}{c}\text { PSM } \\
\text { kernel }\end{array}$} & \multicolumn{2}{|c|}{$\begin{array}{l}\text { Logistic } \\
\text { regression }\end{array}$} & \multicolumn{2}{|c|}{$\begin{array}{l}\text { PSM } \\
\text { caliper }\end{array}$} & \multicolumn{2}{|c|}{$\begin{array}{c}\text { PSM } \\
\text { kernel }\end{array}$} \\
\hline & & -0.9 & & 5.0 & 0.4 & & -12.4 & ** & -11.9 & * & -11.5 & $\star \star \star *$ \\
\hline & & 4.3 & * & 8.8 & 5.2 & * & 11.7 & $\star \star \star$ & 12.2 & ** & 11.6 & $* * *$ \\
\hline \multirow[t]{2}{*}{ Czech } & tertiary & -3.4 & & -8.6 & -2.0 & & 9.6 & & 1.2 & & 2.8 & \\
\hline & secondary & 5.0 & & 2.3 & 2.5 & & 14.0 & ** & 11.0 & ** & 13.6 & $\star \star \star *$ \\
\hline \multirow[t]{2}{*}{ Denmark } & tertiary & -5.6 & * & -4.0 & -3.7 & * & -3.4 & & -1.7 & & -2.3 & \\
\hline & secondary & -10.5 & ** & -11.0 & -4.5 & & 12.8 & $\star \star \star$ & 11.8 & ** & 10.8 & $\star \star \star *$ \\
\hline Finland & $\begin{array}{l}\text { tertiary } \\
\text { secondary }\end{array}$ & $\begin{array}{l}-2.6 \\
-1.6\end{array}$ & & $\begin{array}{l}-4.1 \\
-3.7\end{array}$ & $\begin{array}{r}0.1 \\
-2.9\end{array}$ & & & & & & & \\
\hline France & $\begin{array}{l}\text { tertiary } \\
\text { secondary }\end{array}$ & $\begin{array}{l}-4.9 \\
-0.4\end{array}$ & & $\begin{array}{r}-2.5 \\
4.1\end{array}$ & $\begin{array}{r}-4.3 \\
3.8\end{array}$ & & $\begin{array}{l}2.0 \\
3.8\end{array}$ & & $\begin{array}{l}3.9 \\
4.2\end{array}$ & & $\begin{array}{r}-2.6 \\
4.1\end{array}$ & \\
\hline \multirow[t]{2}{*}{ Germany } & tertiary & -2.3 & & -6.3 & -1.0 & & -22.0 & & -23.0 & *** & -13.5 & ** \\
\hline & secondary & -10.6 & ** & -7.7 & -5.8 & & 1.2 & & 9.8 & * & 3.7 & \\
\hline \multirow[t]{2}{*}{ Ireland } & tertiary & 1.5 & & 0.1 & -0.1 & & & & & & & \\
\hline & secondary & 7.7 & ** & 3.3 & 3.1 & & & & & & & \\
\hline \multirow[t]{2}{*}{ Italy } & tertiary & -9.7 & & na & na & & -6.2 & & na & & -9.4 & \\
\hline & secondary & 9.5 & $\star \star \star$ & 4.1 & 6.5 & ** & 2.6 & & 4.8 & * & 4.0 & \\
\hline \multirow[t]{2}{*}{ Netherlands } & tertiary & -2.5 & & -2.6 & -3.3 & & -1.4 & & 2.4 & & -1.0 & \\
\hline & secondary & -0.1 & & 3.8 & 2.8 & & 15.2 & $\star \star \star$ & 16.3 & $\star \star \star$ & 18.5 & $\star \star \star$ \\
\hline \multirow[t]{2}{*}{ Norway } & tertiary & 0.1 & & -1.9 & 0.1 & & 0.2 & & 1.6 & & 1.8 & \\
\hline & secondary & -2.9 & & -3.5 & -1.0 & & 1.9 & & -1.2 & & 1.9 & \\
\hline \multirow[t]{2}{*}{ Poland } & tertiary & 2.2 & & 1.0 & 0.2 & & 2.0 & & 2.3 & & 0.1 & \\
\hline & secondary & -1.3 & & 4.7 & 1.8 & & 9.7 & ** & 5.8 & & 9.9 & $\star * * *$ \\
\hline \multirow[t]{2}{*}{ Slovak Rep } & tertiary & -7.6 & & na & -1.8 & & 0.9 & & na & & na & \\
\hline & secondary & -1.6 & & -2.0 & 0.0 & & 13.1 & $\star \star \star$ & 11.9 & * & 16.0 & $\star \star \star *$ \\
\hline \multirow[t]{2}{*}{ Spain } & tertiary & -4.0 & & -5.9 & -4.7 & & 6.1 & & 3.0 & & 9.7 & * \\
\hline & secondary & -0.4 & & -7.0 & 0.0 & & -2.4 & & -4.2 & & -1.0 & \\
\hline \multirow[t]{2}{*}{ Sweden } & tertiary & 1.6 & & -1.9 & 0.1 & & & & & & & \\
\hline & secondary & -0.9 & & 5.2 & 3.3 & & & & & & & \\
\hline \multirow[t]{2}{*}{ UK } & tertiary & 8.0 & 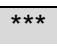 & 3.4 & 5.4 & ** & -1.9 & & 0 & & -2.6 & \\
\hline & secondary & 0.3 & & -2.6 & 1.8 & & 1.5 & & 2.1 & & -1.0 & \\
\hline
\end{tabular}

Note: this table presents percent point differences in being in employment (column 1 to 3 ) and holding professional positions (column 4 to 6 ) between upper secondary educated adults with and without dropout experience (second row each country) and tertiary educated adults with and without dropout experience (first row each country) by method used. Shaded cells denote significance, ${ }^{* \star}$ denotes $p<0.01,{ }^{* *} p<0.05$ and ${ }^{*} p<0.1$. All results are conditioned on socio-economic and demographic background, work experience and cognitive skills (model 3 pervious Table). For three countries (Sweden, Ireland and Finland) information on profession were not available. 'na' denotes that the propensity score matching resulted in an average mean bias across coefficients bigger than 8 percent. 
Figure 1: Self-reported dropout rates by working-age adults from PIAAC and dropout rates from student population cross-cohorts and panel data

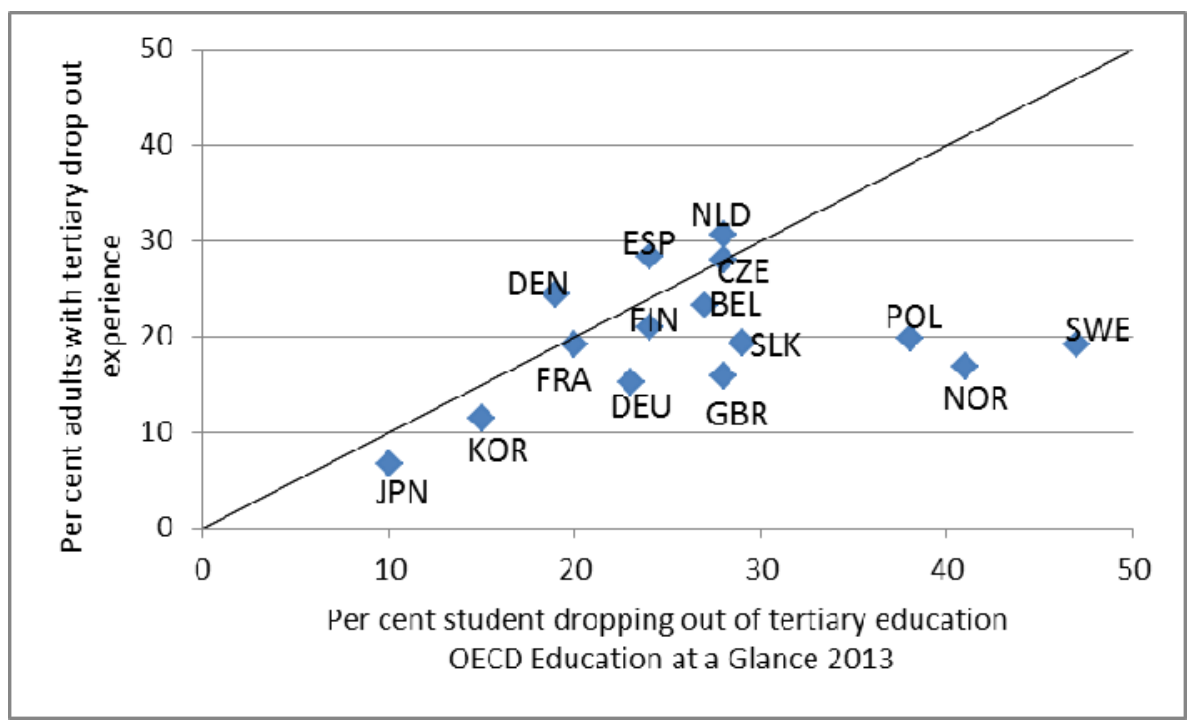

Note: Belgium refers to the Flemish speaking part only for both measures. Correlation coefficient is 0.41 including the OECD countries Korea and Japan and 0.0 without. If the three countries with highest dropout rates using the OECD measure are excluded (Poland, Norway and Sweden), the coefficient is 0.71 .

Source: OECD 2013, for Korea and Spain OECD 2010 and for Germany OECD 2008, author's calculations. 
Figure 2: Percentage of population having attained tertiary education and percentage of students having ever been enrolled in tertiary education who dropped out of tertiary education

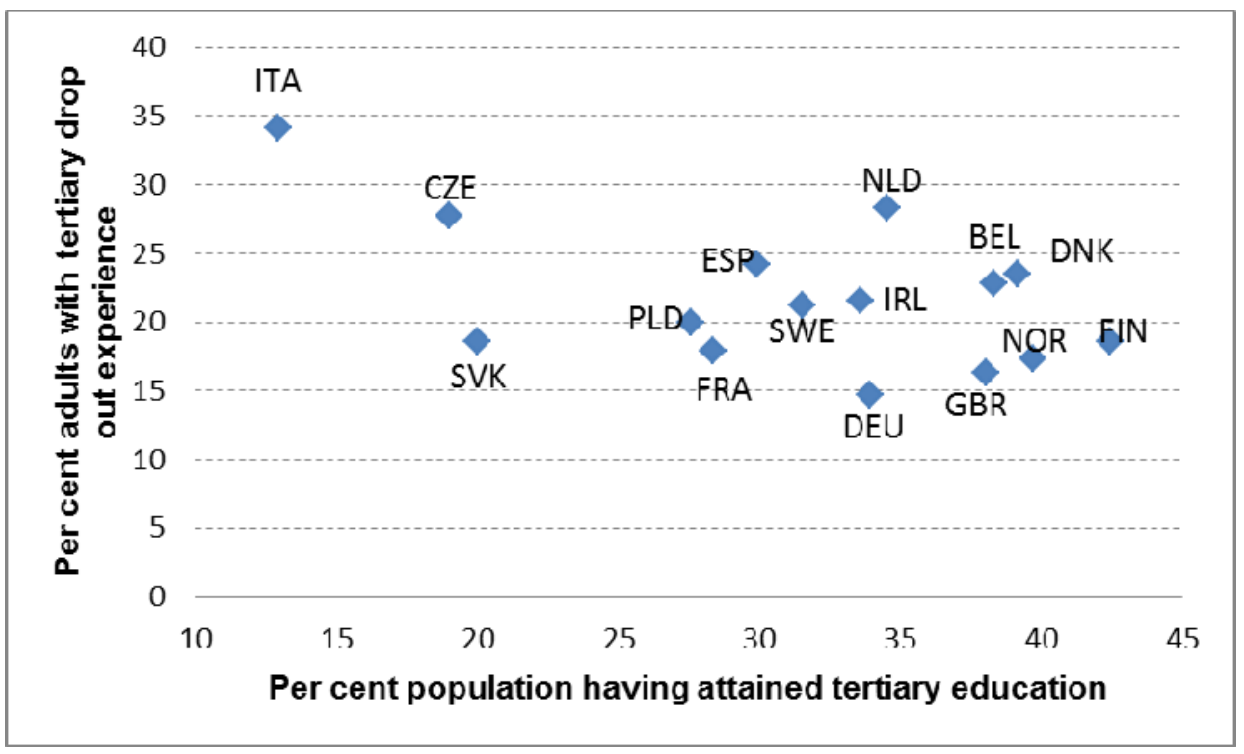

Note: Adults are aged 25 to 64, individuals in education are excluded. Using all countries the correlation coefficient is -0.54 . Excluding Italy from the correlation increases the coefficient to -0.25 , excluding in addition the Czech Republic leads to a correlation of 0 . 
Figure 3: Percentage of tertiary enrolled students dropping out of education and percentage of dropout students having attained tertiary education after drop out

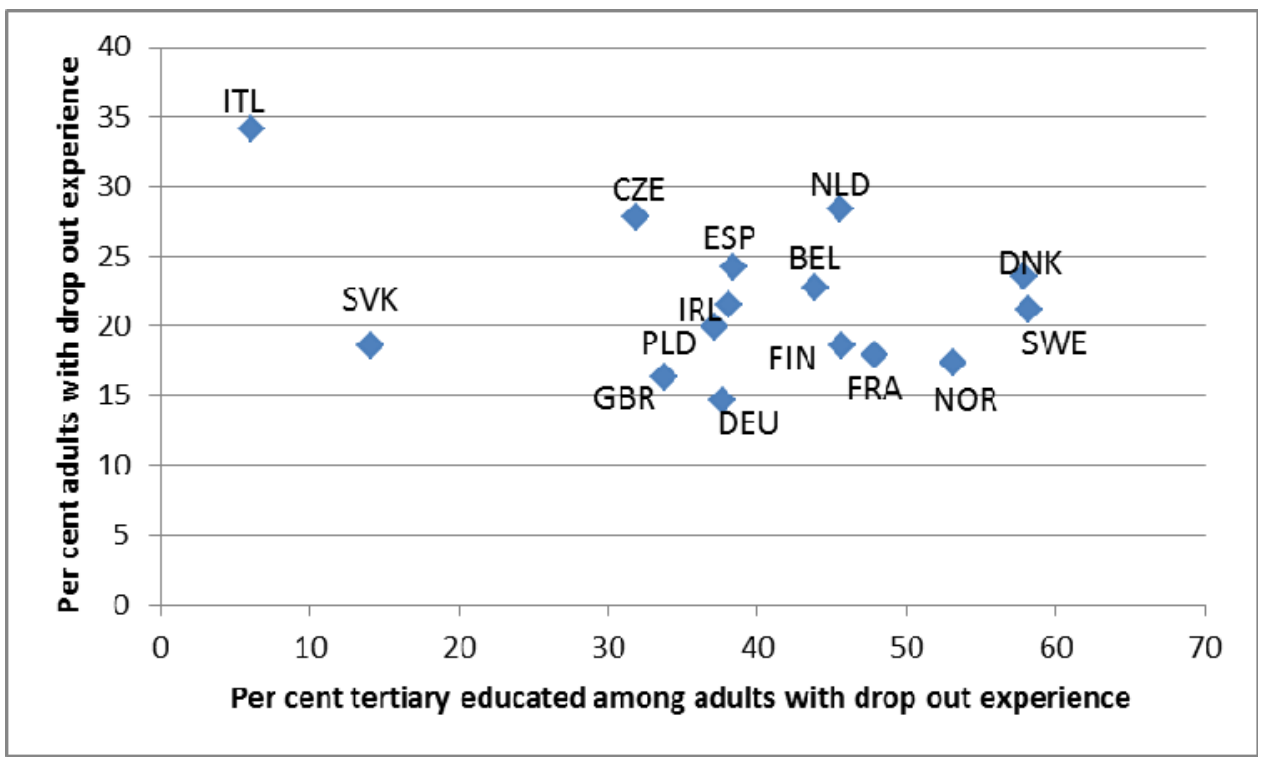

Note: correlation coefficient is 0.09 . Excluding Italy form the calculation increases the correlation coefficient to 0.45 . 
Figure 4: Adults reporting tertiary drop out expressed as percentage of all adults having enrolled in tertiary education by age group

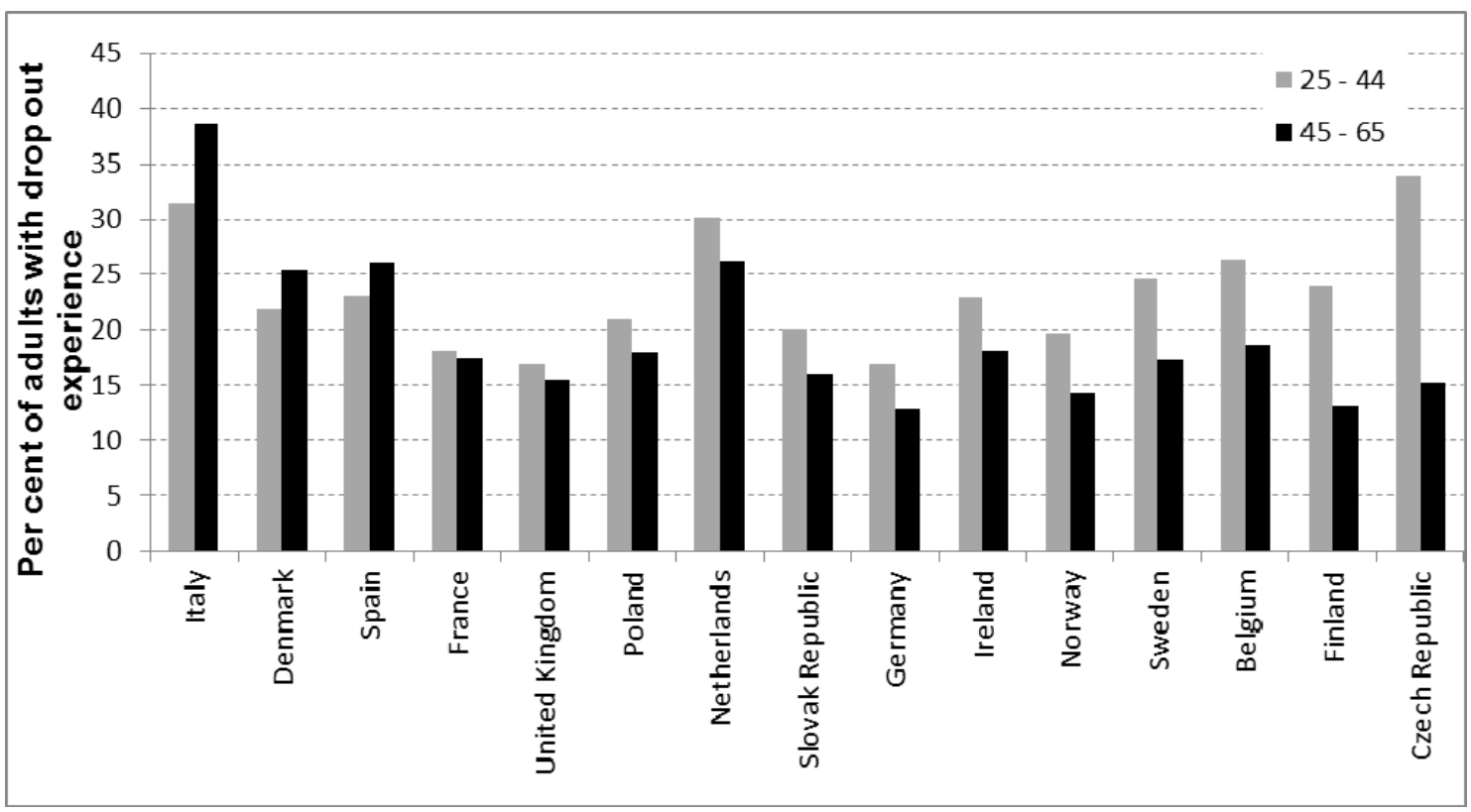

Note: Differences between age groups are significant at the 5 per cent level for the following countries: Czech Republic, Italy, Belgium, Spain, Finland, Denmark and Norway. Countries are ordered by percentage point difference in dropout between age groups. 


\section{References}

Angrist, J. and Pischke, J.S. (2008), Mostly Harmless Econometrics: An Empiricist's Companion, Princeton University Press.

Araque, F., Roldan, C. and Salguero, A. (2009), Factors influencing university drop out rates, Computers \& Education, 53, 563-574.

Arrow, K.J. (1973), Higher education as a filter. Journal of Public Economics, 2, 193216.

Aubyn, M., Pina, A., Garcia, F. and Pais, J. (2009), Study on the efficiency and effectiveness of public spending on tertiary education, European Commission Economic Papers.

Becker, G. S. (1962), Investment in in human capital: a theoretical analysis, The Journal of Political Economy, 70, 9-49.

Bennet, R. (2003), Determinants of undergraduate student dropout out rates in university business studies department, Journal of Further and Higher Education, 27(2), 123-141.

Bound, J. and Turner, S. (2007), Cohort crowding: how resources affect collegiate attainment, Journal of Public Economics, 91(5-6): 877-899.

Buchner, C., Smits, W. and Velden, R. van der, 2012, Education, cognitive skills and earnings of males and females, Research Memoranda 010, Maastricht: METEOR, Maastricht Research School of Economics of Technology and Organization.

Cataldi, E., Laird, J and KewalRamani, A. (2009), High School Dropout and Completion Rates in the United States: 2007,National Center for Education Statistics, U.S. Department of Education, Wasington, DC. http://nces.ed.gov/pubsearch/pubsinfo.asp?pubid=2009064.

Cingano, F. and Cipollone, P. (2007), University drop-out: The case of Italy, Banca D'Italia, Economic Department Discussion paper No. 626.

Davies, R. and Elias, P. (2003), Dropping out: A study of early leavers from higher education, Research Report RR386, Norwich: Department for Education and Skills.

Flores-Lagunes, A. and Light, A. (2007), Interpreting sheepskin effects in the returns to education, University of Arizona Economic Working Paper Series, 07-07. 
Heublein, U., Richter, R., Schmelzer, R. and Sommer, D., Die Entwicklung der schwund- und Studienabbruchquoten an den deutschen Hochschulen, HIS: Forum Hochschule, 3/2012, http://www.his.de/pdf/pub_fh/fh-201203.pdf

Jones, J. and McNabb, R. (2004), Never give up on the good times: student attrition in the UK. Oxford Bulletin of Economics and Statistics, 66, 23-47.

Kupfer, Meyer and Schnepf (2014), How can international tertiary education dropout be explained?, S3RI Applications and Policy paper, forthcoming.

Manski, C. (1989), Schooling as experimentation: a reappraisal of the postsecondary dropout phenomenon, Economics of Education Review 8(4), 305-312.

Matkovic, T. and Kogan I. (2012), All or Nothing? The Consequences of Tertiary Education Non-Completion in Croatia and Serbia, European Sociological Review 28 (6).

Mincer, J. (1974), Schooling, Experience, and Earnings, New York: NBER.

Montmarquette, C., Mahsweredjian, S. and Houle, R. (2001), The determinants of university dropouts: a bivariate probability model with sample selection, Economics of Education Review, 20(5), 475-484.

NCIHE (1997), The national Committee of Inquiry into Higher Education, http://www.leeds.ac.uk/educol/ncihe/

OECD (2000), From Initial Education to Working Life, Making Transitions Work, OECD, Paris.

OECD (2013a), Education at a Glance

OECD (2013b), Technical Report of the Survey of Adult Skills (PIAAC), http://www.oecd.org/site/piaac/ Technical\%20Report 170CT13.pdf

OECD (2013c), Background questionnaire, www.oecd.org/edu/48442549.pdf (previous a - channge)

OECD (2011), Education at a Glance, www.oecd.org/dataoecd/61/2/48631582.pdf

OECD (2010a), PIAAC Technical Standards and Guidelines, http://www.oecd.org/site/piaac/PIAAC-

OECD (2010b), Education at a Glance, www.oecd.org/dataoecd/45/39/45926093.pdf

OECD (2008), Education at a Glance, http://www.oecd.org/education/skills-beyondschool/41284038.pdf

OECD (1999), Classifying Educational Programmes. Manual for ISCED-97 Implementation in OECD Countries, http://www.oecd.org/edu/1841854.pdf 
Powdthavee, $\mathrm{N}$ and Vignoles, A (2009), The socio-economic gap in university dropout, http://powdthavee.co.uk/resources/socio econ edu powdthavee vignoles.pdf

Schofer, E and Meyer J. (2005), The Worldwide Expansion of Higher Education in the Twentieth Century, American Sociological Review, 70(6), 898-920.

Smith, J. and Naylor, R. (2001) Dropping out of university: a statistical analysis of the probability of withdrawal for UK university students, Journal of Royal Statistical Society, 164, 389-405.

Stinebrickner, R. and Stinbrickner, T. (2013), A Major in Science? Initial Beliefs and Final Outcomes for College Major and Dropout, www.ecfonomics.uwo.ca/people/stinebrickner docs/amajorinsciencejuly13.pdf

Stratton, L., O'Toole, D. and Wetzel, J. (2007): A multinomial logit model of college stopout and dropout behaviour, Economics of Education Review 27: 319-331.

Tinto,V. (1975), Dropout from Higher Education: A Theoretical Synthesis of Recent Research, Review of Educational Research, 45, 89-125.

Wolbers, M. (2007): patterns of Labour market Entry: A Comparative Perspective on School-to-Work Transitions in 11 European Countries, Acta Sociologica, 50: 189-211. 